\title{
Praising Māori children: getting it right
}

\section{Veronica Butterworth and Jill Bevan-Brown}

$\mathrm{I}$

n the context of this study, praise refers to the expression of approval, admiration, and support of students' efforts, achievements, abilities, and qualities. Praise can be expressed verbally and nonverbally, and can be both tangible and intangible in form.

Despite the wealth of evidence that teacher praise can assist students' learning, raise their self-esteem, increase their motivation, and reduce disruptive behaviour (Brophy, 1981; Schunk, 1990; Sutherland, Wehby, \& Copeland, 2000), many well-meaning teachers are reluctant to praise their Māori students (Bevan-Brown, 1999). This is either because they believe it is culturally inappropriate to do so, or because they have experienced Māori students being uncomfortable when praised. Given the many potential benefits of teacher praise, this present research sought to gain more information about Māori students' reaction to praise by consulting with the students themselves. More specifically, the study investigated:

1. What were Māori students' interpretations and response to teacher praise and positive feedback?

2. What influenced their response to praise and positive feedback?

3. What effect did whakamā (shyness, embarrassment, shame) have on Māori students?

4. What impressions did one teacher have of her Māori students' interpretation and response to teacher praise?

\section{Methodology}

The participants consisted of nine Years 5 and 6 Māori students from a Years 4 to 6 bilingual class. They ranged in age from 9 to 11 years. The class was located in a decile 2, mainstream urban primary school with Māori students making up 70 percent of the school's roll. The teacher involved was Māori and had been teaching in the bilingual class for five years. Previously, she had taught in a total immersion class for five years.

Prior to beginning the research, approval was gained from the Massey University Human Ethics Committee, the school principal, and the board of trustees, the teacher, and the students' parents. A whānau hui (conducted according to Māori protocol) and another during school time with the bilingual students, were held where the researcher explained and discussed her study with the whānau and students who attended.

Students filled in a written questionnaire, and six students whose responses indicated they were either most influenced by whakamā, or least influenced by whakamā, were selected for semistructured individual interviews. Students were asked to comment further on the feelings they had when they were praised, and on what other things would encourage them to work harder in the classroom. They were also asked about what they thought would help their classmates to feel good when the teacher praised them, and to comment on the established practices of teacher feedback to parent/whānau and the "raru hui".

In an interview with the teacher, questions centred on: Māori students' responses and interpretations of praise and positive feedback; how Māori students respond to verbal and nonverbal praise; and what influences students' responses to praise and positive feedback. The teacher was also asked to comment on strategies which may encourage Māori students in their learning and behaviour.

When the study was completed, a poroporoāki (farewell) hui was held at the school. The researcher met with the teacher, students, and whānau to share the research findings (kōrero whakamārama). The poroporoāki enabled a formal closure of the research through kōrero (talk), acknowledgements, and farewells. 


\section{Findings}

\section{Student data}

All students reported feeling "very glad" or "glad" and "very proud" or "proud" when their teacher praised them. They also reported feeling excited, shy, or happy when praised. Typical comments were:

Sometimes I feel excited or really happy and I always smile when she says something nice to me.

I get shy or I say yes or I am da bomb! Students reported several ways that the teacher could communicate her positive impression of their work and behaviour-verbally through messages about their effort and achievement, and through tokens such as stickers or ticks:

I would like the teacher to tell me how

she is feeling about my work.

Awesome work or put my name on the happy face.

However, one student noted that he did not like it when he was not happy with his work but the teacher said it was okay. Another student reported feeling shy when the teacher showed her nice work to the class.

All students understood the concept of whakamā, defining it as being embarrassed, shamed, ashamed, shy, shamed out, or uncomfortable. Six students reported feeling degrees of shame/embarrassment when they were praised by their teacher. However, when all students were asked if they would rather not be praised if they felt both shame and pride, everyone replied that they would still rather be praised than have their efforts and achievements go unacknowledged.

In the individual interviews, the response of feeling both shamed and proud of being praised was probed further. One student who reported feeling "really shamed" in her questionnaire indicated a strong preference for verbal praise as a strategy to motivate and encourage her and her peers in the classroom. Praise for effort was expressly mentioned as being important to her. A second child who reported feeling shamed and shy when praised also mentioned in his interview that he preferred to be praised in front of the whole class rather than quietly, one-to-one by the teacher- "In front of the whole class so they know I'm da bomb." For this child, praise was both verbal and nonverbal: "They might look at you in a nice way or say good stuff." He believed certificates and activity rewards were an effective way of encouraging students to feel good and try harder with their work. This student mentioned that he told his parents when he did well at school and received further affirmation from them. The interview revealed that for these two pupils the shamed reaction to teacher praise reported in their questionnaire was just one dimension of their praise response.

The four students least influenced by whakamā noted in their individual interviews that they had received praise for a variety of reasons, and had experienced both verbal and nonverbal praise: "She has a smile on her face ... when she looks at my book." Suggestions for ways their teacher could make them and others work harder included: giving and checking nightly homework; regularly monitoring work to ensure it is up to date; providing extra help for those who needed it especially with "hard work"; and letting students "out to play" as a reward for trying hard with their work. One child mentioned that he helped his peers who were too shy to seek help from the teacher by putting his hand up: "Some of the people don't go up and ask 'cause they're kinda scared ... I just put my hand up and tell her that they need anything ...”

Five of the six students who were interviewed mentioned that they received positive feedback from their parents when they achieved in the classroom. Typical comments were:

They give me presents.

They say 'very good son'.

Oh, she just says good boy and kisses me.

A regular feature of the classroom programme is the "raru hui", the purpose of which is to give students an opportunity to speak about any raruraru (problems) they may be experiencing either in the classroom or in the playground. All students were able to describe the process and the purpose of the raru hui, which provided a collective forum for them to talk through their issues and to decide on a consequence for any misdemeanours. Typical responses included:

We sit in a circle and she asks us if we've got any raru and we go around in the circle then they just tell her ... it's about if someone has done something bad to someone else so it's good if someone is bullying you can just tell.

Like if some things are hurting us inside they just have to say it like if someone is being cheeky to me then I just tell on them, it's like a telling thing.

\section{Teacher data}

The teacher reported a range of student responses to praise. Notably, responses had changed as the year progressed:
I know at the beginning of the year I've said well done, they'd just put their head down and I don't know why ... [later in the year] their smile comes up and also the rest of the class helps with the praise. They either clap or they're also praising the student as well in their group.

The teacher also reported that she had noticed a change over the years in the way Māori students interpret praise. There had been a shift from a negative to a positive interpretation. This view was based on her observations of the gradual change of body language displayed by students when they were praised. She also noted the positive effect of praise and rewards on students' motivation and effort.

The teacher listed a variety of factors she believed assisted Māori students to respond positively to praise. These included:

- providing achievement-focused feedback and actively supporting students in their learning - the teacher's high expectations of her students were communicated via specific feedback which let them know why they were being praised

- creating a whānau classroom environment where students care for and support one another

- regularly communicating to students what is expected of them

- letting students know when they are working well and when they are not

- encouraging students to acknowledge their classmates' achievements-when individuals had success in their learning, the teacher would ask the class to "hōmai te pakipaki" (give them a clap)

- providing external rewards-telling students early in the year what end-ofterm/year prizes they could work for, using tokens and certificates to acknowledge good behaviour

- encouraging students to reflect more critically on what achievement "looked like" in the activities they had undertaken

- acknowledging both "best" individual achievements and smaller steps achieved within a given task or activity

- instructing students to tell their parents about their successes in the classroom

- encouraging parents to visit the classroom and informing them of their children's achievements

- providing positive feedback to students from the principal and deputy principalon scheduled class visits, the principal would look through the students' books and add a tick or signature. Similarly, once 
a term the deputy principal would collect the students' sample books and write comments in them.

The teacher did not believe there was any difference in Māori students' response to verbal and nonverbal praise. She also noted that children's positive response to praise was limited when they were tired, hungry, or experiencing problems at home.

From her experience of teaching Māori children, the teacher found two particular strategies effective in reinforcing and encouraging good work and behaviour. Firstly, there was the whānau process of hui which provided an opportunity for students to resolve their difficulties through collaborative discussion and problem solving. These hui helped students to get on with their learning rather than worry about their problems. It was added, however, that hui were not just about dealing with negative issues; positive matters were also discussed:

The whānau concept where we all sit down and discuss whether it be a raru or something else I think from that it's a big help ... I think having the whānau concept in a class is a big factor knowing that someone's there cheering for them to achieve what they want to do ... and knowing that the raru session is on Friday they might come in and say, 'Give me a raruraru session now cause I need to get it out now' ... I let the students talk first and that way they can sort it out and then I go, 'Well what do you think? What shall we do?' And then the kids go, 'Well what do you think?'

A second strategy the teacher used was to share with her students some of her own personal experiences as a student at school and as an employee before becoming a teacher. This sharing and discussion often prompted the students to think about what they wanted to do when they left school and initiated class discussion about the educational requirements for different career pathways.

A final suggestion from the teacher was to invite kuia, kaumātua, and positive Māori role models to the school. She acknowledged that the support for such initiatives would need to come from both the school's principal and the wider school staff. She noted the difficulties teachers who were not from the local iwi may have in knowing and accessing kuia and kaumātua from the local school area.

\section{Discussion}

This research revealed that Māori students' response to praise was a complex, multifaceted issue that was firmly grounded in a cultural framework. The following model (see Figure 1 ) is presented as a means of explaining and understanding the many cultural complexities involved.

\section{FIGURE 1 MODEL OF A CONTEXT OF PRAISE}

\begin{tabular}{|l|l|}
\hline \multicolumn{1}{|c|}{ Te Take } & \multicolumn{1}{c|}{ Te Āhua } \\
\hline Whakamihi & $\begin{array}{l}\text { kōrero whakamana } \\
\text { achievement } \\
\text { effort }\end{array}$ \\
\hline Whanaungatanga & $\begin{array}{l}\text { respectful } \\
\text { caring } \\
\text { reciprocal } \\
\text { hui }\end{array}$ \\
\hline $\begin{array}{l}\text { Manaakitanga/ } \\
\text { mana-a-ki }\end{array}$ & $\begin{array}{l}\text { encourage } \\
\text { support } \\
\text { acceptance }\end{array}$ \\
\hline Whānau/mātua & $\begin{array}{l}\text { kōro whakamana } \\
\text { kanohi ki te kanohi } \\
\text { inclusion }\end{array}$ \\
\hline
\end{tabular}

\section{Whakamihi (praise)}

While there is considerable debate over what constitutes praise and how it should be imparted, there is general agreement in the literature over the following basic principles. Praise should be genuine; specifically focused and contingent on the desired behaviour or outcome; descriptive; timely; and given for both effort and achievement (Alberto \& Troutman, 2003; Bevan-Brown, 1999; Brophy, 1981; Good \& Brophy, 1997; Landrum, Tankersley, \& Kauffman, 2003; Sutherland, Copeland, \& Wehby, 2001). These praise components were all identified in the study and consistently used in the classroom. Praise took many forms including verbal and written acknowledgement, nonverbal smiles and pats on the back, and tangible rewards. Teacher expectations and the effect on students' self-concepts and their view of themselves as effective learners are well documented in the literature (Badad, 1993; Good \& Brophy, 1997; Schunk, 1990). Consistent messages from the teacher, the principal, and deputy principal added to the classroom "talk", which communicated to the students what the expectations of them were with respect to their learning and behaviour. These messages became part of the dominant classroom discourse which focused on achievement and effort in order to have learning successes. By openly and consistently sharing this belief with their students, the teacher and senior staff helped build the students' awareness of themselves as effective learners.

\section{Whanaungatanga}

Whanaungatanga contributed to the building and sustaining of reciprocal relationships among the students and their teacher. This positive relationship was at the foundation of the "whānau concept" which the teacher had committed to build within her classroom.

Caring and respectful relationships with and between the teacher and students, her invitation and encouragement of parents to become part of the classroom whānau, and regular information sharing with parents which focused on their children's learning progress, all contributed to the development of whanaungatanga within the classroom. Whanaungatanga was reflected in the interview responses of the students. They acknowledged the care and support the teacher had for them, her desire that they succeed in their learning, and the collective whānau nature of the classroom.

The practice of regular raru hui to discuss and resolve problems also contributed to developing and maintaining the whānau environment. As a collective process, hui assists to maintain social order through its formal approach to resolving conflict or disorder. Hui is a cultural practice which enables Māori "to continue with our own way of life within the total structure of our own terms and values" (Walker, 1987, p. 147). In this classroom, regular hui not only helped students to problem solve and resolve existing conflict, but also assisted in decreasing their anxiety and stress and preventing possible future outbursts caused by unresolved classroom and playground issues. Through a process of co-operative and respectful kōrero, students contributed to maintaining the order and social balance of the whānaufocused classroom environment. Additionally, the practice of student-initiated hui allowed students the opportunity to demonstrate a high level of social responsibility.

\section{Manaakitanga/mana-a-ki}

Manaakitanga encompasses the values of caring for others and respectful interactions between people and their environment. Manaakitanga is intrinsic to whanaungatanga, both concepts of which encompass the values of aroha and āwhina. Aroha is described as love of one's whānau, hapū, and iwi (Metge, 1995) while āwhina and awhi involve assisting and 
caring for others (Pere, 1982; Ryan, 1995). By supporting and encouraging caring and respectful relationships among the students and between herself and the students, the teacher created a classroom environment in which the students felt safe, supported, and accepted as members of the class whānau. Showing care and respect toward their classmates enhanced the students' sense of themselves as caring and respectful people, and by displaying manaaki toward others, the students' individual mana was enhanced (Barlow, 1991; Durie, 2001; Henare, 1988). This sense of themselves as worthy people was reflected in the students' questionnaires and interviews. The values of manaakitanga provided the frame within which the students began to see themselves as people who were worthy of praise.

\section{Whānau/mātua}

Inclusion of the parents as praisers of their children was initiated by the teacher who asked her students to inform their parents of their successes and achievements at school. The teacher also checked that her students had taken their certificates and tokens home to share with their parents. She informed parents of their children's successes through: kanohi ki te kanohi (face-to-face) encounters; during whānau hui; when parents visited the classroom during the term; and at parent interview time. The sharing of this achievement information with parents not only became a kōrero whakamana (a conversation which enhanced the child's reputation), it also embraced the parents/whānau within the "reflected glory" of their child's successes and engaged them in the process of their child's learning.

Incorporating parents into the school through practices that are familiar and understandable to them has been demonstrated to help children have success at school (McNaughton, Glynn, \& Robinson, 1981). The teacher's efforts to include the parents in their child's learning successes demonstrated to both the students and the parents her genuine interest in the students and her desire that they succeed in their learning. This connection with the parents became the foundation on which a praise pathway between the school and the home was created.

Praise messages that originated in the classroom were taken into the home by the student who delivered this teacher feedback to their parents. The parents then reciprocated by returning the praise to their child. This home-based parent/child praise interaction strengthened the classroom-based teacher/ student praise messages and further enhanced the children's belief in themselves as effective learners. Parental expectations of their child's performance were shown to affect the child's commitment to their work at school (Hill \& Yeung, 2000, as cited in Biddulph, Biddulph, $\&$ Biddulph, 2003). By being kept informed of their child's learning successes, the parents' aspirations and expectations for their child's academic achievement were increased. This kōrero whakamana added not only to the child's view of themselves as learning achievers, but also to the adults' view of themselves as parents and supporters of their child's learning. Within this praise pathway, a twoway positive praise process developed with the parents influencing the children's perceptions of themselves as educational achievers and the children influencing their parents' view of themselves as competent parents.

This praise pathway is demonstrated in Figure 2, representing the directional flow of praise within the classroom context.

Within ngā ara whakamihi, praise and positive feedback to the student originated not from the student but from significant others in their environment. This notion is captured in the following whakatauāki (proverb):

E kore te kūmara e kōrero ana mō tōna ake reka.

Engari māku e whakatau māku hoki e kōrero.

It is not for the kūmara to say how sweet it is.

However it is for me to decide and to proclaim.

\section{Challenging some myths}

1. Mãori children don't like to be praised Certain findings in this study would seem to

FIGURE 2 NGĀ ARA WHAKAMIHI (PRAISE PATHWAY)

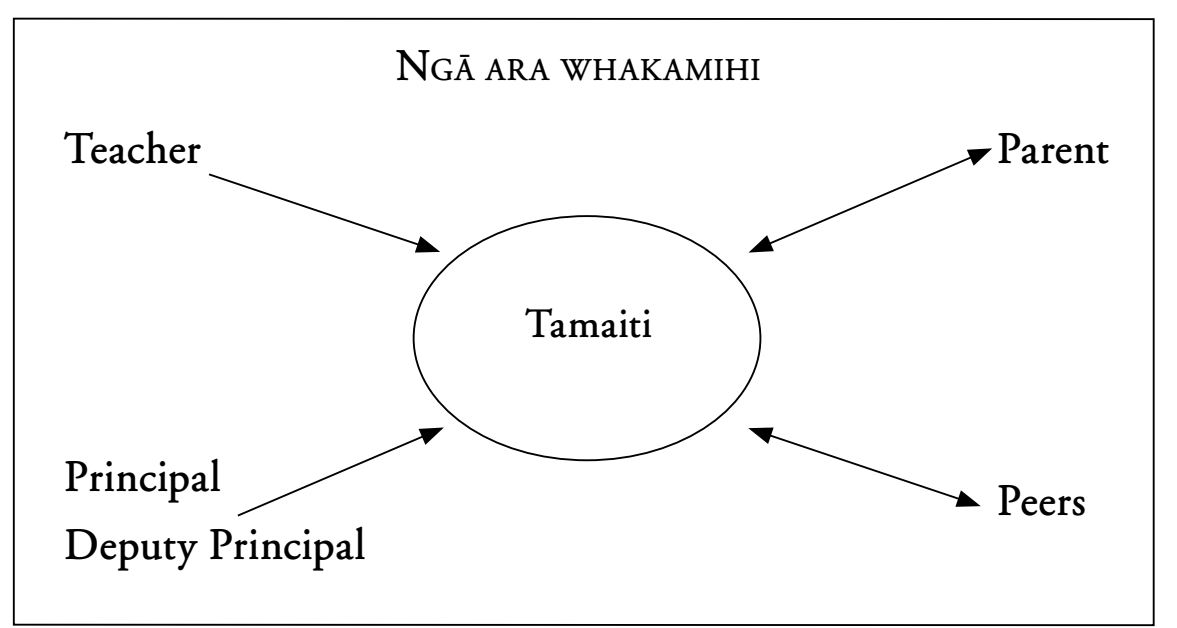

support this contention. Firstly, the teacher reported that at the beginning of the year some children in her class were uncomfortable with praise. However, because of her awareness and understanding of their apparent negative responses, she did not interpret this behaviour as indicating they did not want to be praised. Rather, the teacher believed the students' responses arose from an unfamiliarity with her, their new class group, and with teacher praise in general. The students were unsure as to whether her praise was genuine or not. The teacher continued to use praise and as the students gained confidence and trust in her, their negative responses to praise decreased markedly. One way the teacher detected this change was through careful observation of her students' body language. Stunned and surprised looks and hanging heads were replaced by smiles and raised heads. Interpreting students' initial negative response to praise through a different cultural lens may possibly lead to teacher praise being discontinued in the belief that students dislike praise. This in turn could have a negative effect on students' perceptions of themselves as effective learners and even on their cultural identity.

A second finding that would appear to support the belief that Māori children do not like to be praised is the fact that a number of students, while feeling glad about receiving teacher praise, also reported being shy and shamed when the teacher praised them. Further discussion with these students revealed that their positive feelings outweighed their negative feelings and that they wanted teacher praise to continue.

The existence of dual feelings towards being praised is an interesting and little recognised phenomenon. One possible explanation 
relates to the Māori concept of hinengaro where thoughts and feelings are inextricably connected to become "a distinctive Māori way of thinking, feeling and behaving” (Durie, 2001, p. 86). The interlinking of emotional and cognitive domains may lead to a continuous interpretation and reinterpretation of praise and result in a duality of responses to it. Another possible explanation relates to Māori students' lived reality. Durie (2003) suggests that most Māori learners are located at the interface of te ao Māori (the Māori world) and te ao whānui (the wider global society). At this interface with its conflicting values, standards, and "ways of being", Māori students may struggle as they seek the meaning of praise by integrating the messages within the praise statements with the seen and unseen contextual influences of the educational setting. If the teacher's praise message conflicts with messages received from the learning environment, confusion and mixed feelings are highly likely. However, whatever the cause of some students' duality of feelings about teacher praise, their desire for this praise to continue was a very clear message from this research.

Teachers need to be aware that some Māori students may experience a duality of feelings in response to praise, and that a student's body language which could suggest a negative response to praise may be occurring concurrently with a positive internal response to praise. This knowledge may prevent the misinterpretation of some Māori students' seemingly negative response to praise. Additionally, an acknowledgement that the classroom environment may affect the student's response and interpretation of praise could assist teachers to understand why some Māori students respond the way they do when they are praised. This latter point is supported by Bevan-Brown (1999) who suggests that rather than judging a whakamā response to praise as signifying that praise is culturally inappropriate for Māori students, cognisance needs to be taken of the context in which praise is delivered.

\section{Māori parents don't praise their children}

It has been suggested that Māori parents avoid praising their children because they fear they may be considered whakahīhī (vain, conceited, arrogant) or their praise may contribute to their children becoming whakahīhī (Metge, 1995). This belief was not supported by the present research findings. Rather, it was shown that within their own whānau where there was no risk of praise being misinterpreted as whakahīhī, parents openly praised and encouraged their children. Bevan-Brown (2004) noted a similar practice.

The question needs to be raised whether the research discourse which reports that Māori parents avoid praising children for fear of being thought whakahīhī has in fact contributed to a further belief that praising Māori children is culturally inappropriate. This question could be a focus for future research.

\section{Publicly praising Māori children is culturally inappropriate}

The previous finding may lead readers to conclude that while praise in private is acceptable, public praise of Māori children is culturally inappropriate. The teacher in this study was not constrained by any perceptions of public praise being culturally inappropriate. On the contrary, she encouraged it, regularly inviting students to publicly applaud their peers' good work. Her behaviour would seem to be in accord with a traditional practice of celebrating in song noteworthy tūpuna (ancestors) and their deeds. Similarly, traditional child-rearing practices have been described as overtly warm, caring, and inclusive. Reports show that a child's value and contribution to the whānau and hapū were communicated through contact, activity, and inclusion, through verbal expressions of praise and the more subtle influences and nuances of nonverbal praise (Hemara, 2000). These insights suggest that any evaluation of praise of Māori children would need to examine not only public and private verbal praise, but also take into account the unspoken praise which can occur through body language, touch, and proximity.

\section{Conclusion}

This study revealed a complexity of factors within educational settings which positively influence Māori students' interpretation and response to teacher praise. The values, practices, and processes contained in Figure 1 , Model of a context of praise, can be used by teachers as a template for building a classroom and school environment which values Māori culture and supports Māori students' learning via the constructive use of praise and positive feedback. The research findings provide insight and guidance to teachers in their interpretation of Māori students' response to praise. They show that consideration should be paid to the influence the wider classroom context can have on students' praise responses. The praising of Māori children in isolation from a culturally supportive educational environment is likely to reduce the potentially positive effect of praise and may elicit a negative response from the student. An ongoing negative response could indicate that the context of praise requires close examination and analysis by the class teacher. The teacher will need to investigate whether students feel that they and their culture are valued by their peers and the teacher themself. In particular, the teacher will need to examine whether they: treat students with respect and work towards building positive teacher-student relationships; have high expectations of their Māori students; incorporate substantial cultural input into the classroom programme and environment; provide a high-quality education which includes interactive teaching strategies that engage students in their learning; utilise teaching strategies that build on students' strengths and interests; and involve parents, whānau, and peers in their students' education (Alton-Lee, 2003; Bevan-Brown, 2002, 2003, 2006; Bishop, Berryman, Tiakiwai, \& Richardson, 2003; Bishop \& Glynn, 1999; Hill \& Hawk, 2000; MacFarlane, 2004).

A further message from the research is that teachers must be alert to the influence their own world views, beliefs, attitudes, and cultural understandings have on their interpretation and reaction to Māori students' responses to praise. To avoid misinterpreting praise responses they must understand the children's cultural influences and be alert to the possibility that some children may experience a duality of feelings in respect to receiving praise. Negative responses to praise cannot be viewed in isolation from the students' cultural beliefs, values, and practices and from the classroom context with its many influences, both seen and unseen.

However, there is no doubt that in a culturally responsive, supportive environment praise can have a powerful positive effect on Māori students' learning and behaviour. It is a strategy that does not require any financial expenditure and is readily available to teachers, students, parents, and whānau. This study involved only a small number of students. In order to generalise findings, research with large samples of children of varying ages in both bilingual and mainstream settings needs to be conducted. Such research will add to the small body of knowledge in this area and, hopefully, result in increasing teacher praise of Māori students. 


\section{References}

Alberto, P. A., \& Troutman, A. C. (2003). Applied behavior analysis for teachers (6th ed.). Upper Saddle River, NJ: Merrill/Prentice Hall.

Alton-Lee, A. (2003). Quality teaching for diverse students in schooling: Best evidence synthesis. Wellington: Ministry of Education.

Badad, E. (1993). Pygmalion-25 years after interpersonal expectations in the classroom. In P. D. Blanck (Ed.), Interpersonal expectations: Theory, research and applications (pp. 125153). Cambridge: Cambridge University Press.

Barlow, C. (1991). Tikanga whakaaro: Key concepts in Māori culture. Auckland: Oxford University Press.

Bevan-Brown, J. (1999). Praising Māori children. Te Ukaipo, 1, 80-85.

Bevan-Brown, J. (2002). Culturally appropriate, effective provision for Māori learners with special needs: He waka tino whakarawea. Unpublished doctoral thesis, Massey University, Palmerston North.

Bevan-Brown, J. (2003). The cultural selfreview: Providing culturally effective, inclusive education for Māori learners. Wellington: New Zealand Council for Educational Research.

Bevan-Brown, J. (2004). Gifted and talented Maori learners. In D. McAlpine \& R. Moltzen (Eds.), Gifted and talented New Zealand perspectives (2nd ed., pp. 171-197). Palmerston North: Kanuka Grove Press.

Bevan-Brown, J. (2006). Teaching Maori students with special education needs: Getting rid of the too hard basket. Kairaranga, 7(special edition), 14-23.

Biddulph, F., Biddulph, J., \& Biddulph, C. (2003). The complexity of community and family influences on children's achievement in New Zealand: Best evidence synthesis. Wellington: Ministry of Education.

Bishop, R., Berryman, M., Tiakiwai, S., \& Richardson, C. (2003). Te Kotahitanga: The experiences of year 9 and 10 Māori students in mainstream classrooms. Wellington: Ministry of Education.

Bishop, R., \& Glynn, T. (1999). Culture counts: Changing power relations in education. Palmerston North: Dunmore Press.

Brophy, J. (1981). Teacher praise: A functional analysis. Review of Educational Research, 51, $5-32$.
Durie, M. (2001). Mauri ora: The dynamics of Māori health. Melbourne: Oxford University Press.

Durie, M. (2003, March). Māori educational advancement at the interface between te ao Māori and te ao whānui. Paper presented at the Hui Taumata Mātauranga Toru. Turangi/Taupo.

Good, T., \& Brophy, J. (1997). Looking into classrooms. New York: HarperCollins.

Hemara, W. (2000). Mãori pedagogies. A view from the literature. Wellington: New Zealand Council for Educational Research.

Henare, M. (1988). Ngā tikanga me ngā ritenga o te ao Māori. Standards and foundations of Māori society. In Royal Commission on Social Policy, The April report: Report of the royal commission on social policy: Vol. 3, Part 1. Future directions (pp. 39-69). Wellington: Royal Commission on Social Policy.

Hill, J., \& Hawk, K. (2000). Making a difference in the classroom: Effective teaching practice in low decile, multicultural schools. Wellington: Ministry of Education, Research Division.

Landrum, T. J., Tankersley, M., \& Kauffman, J. M. (2003). What is special about special education for students with emotional or behavioral disorders? Journal of Special Education, 37(3), 148-156.

MacFarlane, A. (2004). Kia hiwa ra! Listen to culture-Māori students' plea to educators. Wellington: New Zealand Council for Educational Research.

McNaughton, S., Glynn, T., \& Robinson, V. M. (1981). Parents as remedial reading tutors. Wellington: New Zealand Council for Educational Research.
Metge, J. (1995). New growth for old. Wellington: Victoria University Press.

Pere, R. (1982). Ako. Concepts and learning in the Maori tradition. Working paper No. 17. Hamilton: University of Waikato.

Ryan, P. M. (1995). The Reed dictionary of modern Māori. Auckland: Reed Books.

Schunk, D. H. (1990). Self concept and school achievement. In C. Rogers \& P. Kutnick (Eds.), The school psychology of the primary school (pp. 70-91). London: Routledge.

Sutherland, K., Wehby, J., \& Copeland, S. (2000). Effect of varying rates of behaviour-specific praise on the on-task behaviour of students with emotional and behavioural disorders. Journal of Emotional and Behavioural Disorders, 8(1), 2-8.

Sutherland, K. S., Copeland, S., \& Wehby, J. H. (2001). Catch them while you can: Monitoring and increasing the use of effective praise. Beyond Behavior, 11(1), 46-49.

Walker, R. (1987). Ngā tau tohetohe: Years of anger. Auckland: Penguin Books.

\section{Suggested further reading}

Butterworth, V. (2004). Māori student interpretation and response to teacher praise in the classroom; what influences this? Unpublished Master of Educational Psychology Project, Massey University, Palmerston North.

This is the full report of the research summarised in the present article. It presents the complete findings of the study and includes an in-depth discussion of them.
Veronica Butterworth (Te Arawa, Ngāti Hurunga te Rangi, Ngāti Rongomai, Ngāti Tumatawera). Veronica's research interests include whānau development, Māori education, and bicultural practice.

Jill Bevan-Brown (Ngāti Wehiwehi, Ngāti Raukawa, Ngai te Rangi, Ngāti Awa). Jill is an associate professor in the School of Curriculum and Pedagogy at Massey University. Her research interests include special education, gifted education, and Māori education.

Email: j.m.bevan-brownळmassey.ac.nz 